\title{
Transfer of Defluvibacter lusatiensis to the genus Aquamicrobium as Aquamicrobium lusatiense comb. nov. and description of Aquamicrobium aerolatum sp. nov.
}

\author{
Peter Kämpfer, ${ }^{1}$ Elena Martin, ${ }^{2}$ Nicole Lodders ${ }^{1}$ and Udo Jäckel ${ }^{2}$ \\ ${ }^{1}$ Institut für Angewandte Mikrobiologie, Universität Giessen, Giessen, Germany \\ ${ }^{2}$ Bundesanstalt für Arbeitsschutz und Arbeitsmedizin, Berlin, Germany
}

Correspondence

Peter Kämpfer

peter.kaempfer@umwelt.uni-

giessen.de
The monospecific genus Defluvibacter was proposed by Fritsche et al. (1999a) for Gram-negative strains isolated from an industrial wastewater-treatment plant that were able to degrade 2,4-dichlorophenol, 4-chloro-2-methylphenol, 4-chlorophenol and phenol. Originally proposed as 'Defluvibacter lusatiae' (sic), the name was corrected to Defluvibacter lusatiensis on validation (Fritsche et al., 1999b). Slightly earlier, the monospecific genus Aquamicrobium was proposed by Bambauer et al. (1998a) for a Gram-negative strain, also isolated from wastewater, that was able to degrade thiophene-2-carboxylate. The two genera were proposed independently. The name Aquamicrobium defluvii was validly published in 1998 (Bambauer et al., 1998b).

A white-greyish strain $\mathrm{Sa} 14^{\mathrm{T}}$ was isolated from air collected in a duck shed on tryptone soy agar (TSA) at $26{ }^{\circ} \mathrm{C}$. The building accommodated 2500 ducks (each 14 months old). Bioaerosol samples were collected by filtration on gelatin filters, with an air sampling rate of $301 \mathrm{~min}^{-1}$. Subsequently, the filters were dissolved and diluted in isotonic $\mathrm{NaCl}$ (up to $10^{-8}$ ). The concentration of strain $\mathrm{Sa} 14^{\mathrm{T}}$, calculated from the number of colonies with an identical morphology in the same dilution step, was approximately $10^{4}$ c.f.u. $\left(\mathrm{m}^{3} \text { air }\right)^{-1}$.

Subcultivation was done on nutrient agar (Oxoid) at $28{ }^{\circ} \mathrm{C}$ for $24 \mathrm{~h}$. On this agar, Sa $14^{\mathrm{T}}$ was able to grow at $10-36{ }^{\circ} \mathrm{C}$, but not at 4 or $45^{\circ} \mathrm{C}$. Growth at $30^{\circ} \mathrm{C}$ was also observed

The GenBank/EMBL/DDBJ accession number for the 16S rRNA gene sequence of strain $\mathrm{Sa} 14^{\top}$ is $\mathrm{FM} 210786$. on TSA and R2A agar, but not on Salmonella-Shigella agar or MacConkey agar (all from Oxoid). The $\mathrm{pH}$ range ( $\mathrm{pH} 4-10$ at intervals of $1 \mathrm{pH}$ unit) and requirement for $\mathrm{NaCl}$ (at $0,1,2,3,5$ and $7 \% \mathrm{w} / \mathrm{v}$ ) were determined using R2A medium. Gram-staining was performed as described by Gerhardt et al. (1994). Cell morphology was observed under a Zeiss light microscope at $\times 1000$ magnification, using cells that had been grown for $24 \mathrm{~h}$ at $28{ }^{\circ} \mathrm{C}$ on nutrient agar (Oxoid). Oxidase activity was tested using oxidase reagent (bioMérieux) according to the instructions of the manufacturer.

The cells were Gram-negative, rod-shaped, non-sporeforming, non-fluorescent and oxidase-positive. Cell morphology and other details are given in the species description.

The 16S rRNA gene was analysed as described previously (Kämpfer et al., 2003). Analysis of the sequence data, including multiple alignment, was performed by using the software package MEGA version 4.0 (Tamura et al., 2007). A distance-matrix method (distance options according to Kimura's two-parameter model) using clustering with the neighbour-joining method (Fig. 1) as well as a discrete character-based maximum-parsimony method (data not shown) were used. In each case, bootstrap values were calculated based on 1000 replications. The 16S rRNA gene fragment obtained from strain $\mathrm{Sa} 14^{\mathrm{T}}$ was a continuous stretch of $1346 \mathrm{bp}$. Sequence similarity calculations indicated that strain $\mathrm{Sa} 14^{\mathrm{T}}$ showed the highest degree of similarity to the type strains of D. lusatiensis $(96.9 \%)$ and 


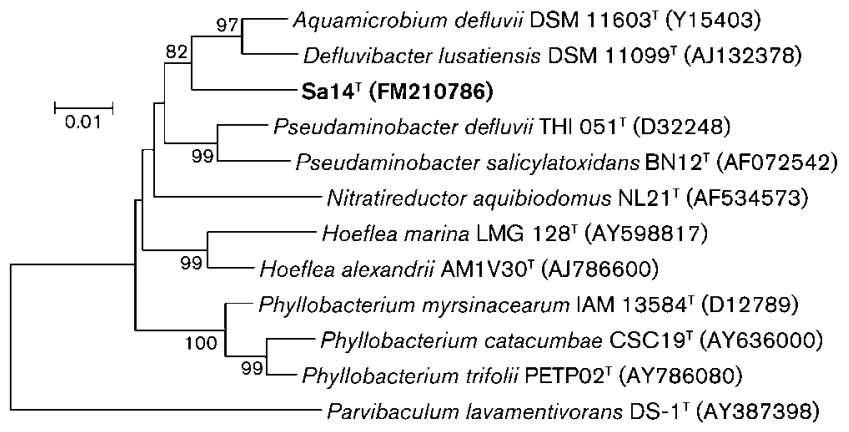

Fig. 1. Phylogenetic analysis based on 16S rRNA gene sequences available from the EMBL database (accession numbers are given in parentheses). Bootstrap values based on 1000 replications are listed as percentages at branching points. Bar, 0.01 substitutions per nucleotide position.

A. defluvii (96.0\%). The 16S rRNA gene similarity between D. lusatiensis DSM $11099^{\mathrm{T}}$ and A. defluvii DSM $11603^{\mathrm{T}}$ was $98.3 \%$. Lower sequence similarities $(<95.5 \%)$ were found with members of the genera Hoeflea (Peix et al., 2005), Pseudaminobacter (Kämpfer et al., 1999) and Nitratireductor (Labbé et al., 2004) of this lineage.

Chemotaxonomic analyses were performed as described by Collins (1985) (respiratory quinones) and Kämpfer \& Kroppenstedt (1996) (fatty acids). Although respiratory quinones have low resolution within this group, the presence of Q-10 supports the affiliation of strain Sa14 ${ }^{\mathrm{T}}$ to this group, where all species investigated to date have Q10 as the major quinone.

The fatty acid profile of strain Sa $14^{\mathrm{T}}$ revealed $18: 1 \omega 7 c$ and 19:0 cyclo $\omega 8 c$ as predominant fatty acids; 11-methyl $18: 1 \omega 7 c$ and $16: 0$ were present in significant amounts and iso-15:0 3-OH was the major hydroxy fatty acid (Table 1). This is essentially in agreement with the fatty acid patterns of A. defluvii DSM $11603^{\mathrm{T}}$ and D. lusatiensis DSM $11099^{\mathrm{T}}$, for which $18: 1 \omega 7 c$ and $19: 0$ cyclo $\omega 8 c$ were also the predominant fatty acids; however, it is obvious that latter two type strains were more similar to each other in their fatty acid profiles than either was to strain Sa $14^{\mathrm{T}}$.

The ratio of the two dominant fatty acids $(18: 1 \omega 7 c$ and 19:0 cyclo $\omega 8 c$ ) differed considerably from the ratio originally reported for $D$. lusatiensis $\mathrm{S1}^{\mathrm{T}}$ (Lechner et al., 1995), probably because of different growth phases of the cells analysed. This phenomenon can be explained by the mechanism of cyclopropane ring formation in fatty acids, which has been described in detail by Grogan \& Cronan (1997). Detailed fatty acid profiles are given in Table 1.

Results of the physiological characterization of Sa14 ${ }^{\mathrm{T}}$ are given in the species description, using methods that were described previously (Kämpfer et al., 1991). Strain Sa14 ${ }^{\mathrm{T}}$ was not able to utilize carbohydrates, organic acids or amino acids under the chosen conditions. Few chromogenic substrates were hydrolysed (Table 2).
Table 1. Fatty acid profiles of the type strains of Aquamicrobium species

Strains: 1 , A. defluvii DSM $11603^{\mathrm{T}}$; 2, A. lusatiensis comb. nov. DSM $11099^{\mathrm{T}} ; 3$, A. aerolatum sp. nov. Sa14 ${ }^{\mathrm{T}}$. Data were obtained in this study; values are percentages of total fatty acids. Strains were grown on TSA at $28{ }^{\circ} \mathrm{C}$ for $48 \mathrm{~h}$ prior to analysis. ND, Not detected.

\begin{tabular}{|lccc|}
\hline Fatty acid & $\mathbf{1}$ & $\mathbf{2}$ & $\mathbf{3}$ \\
\hline $12: 03-\mathrm{OH}$ & 0.5 & 0.4 & $\mathrm{ND}$ \\
$15: 0$ & $\mathrm{ND}$ & $\mathrm{ND}$ & 0.8 \\
Summed feature $2^{*}$ & $\mathrm{ND}$ & $\mathrm{ND}$ & 0.8 \\
Summed feature $3^{*}$ & 0.4 & 0.6 & 0.7 \\
$16: 0$ & 3.7 & 5.0 & 5.2 \\
iso-15:0 3-OH & $\mathrm{ND}$ & $\mathrm{ND}$ & 3.0 \\
$17: 1 \omega 8 c$ & 1.2 & 0.8 & 1.4 \\
$17: 1 \omega 6 c$ & 1.4 & $\mathrm{ND}$ & 1.5 \\
$17: 0$ cyclo & $\mathrm{ND}$ & 1.8 & $\mathrm{ND}$ \\
$17: 0$ & 2.5 & 0.6 & 6.9 \\
$18: 1 \omega 7 c$ & 36.7 & 28.6 & 27.4 \\
$18: 0$ & 3.5 & 1.6 & 1.7 \\
$11-$ Methyl $18: 1 \omega 7 c$ & 0.7 & 1.7 & 10.5 \\
$19: 0$ cyclo $\omega 8 c$ & 46.8 & 53.7 & 33.9 \\
$20: 2 \omega 6,9 c$ & 0.6 & 1.2 & 0.9 \\
$20: 1 \omega 7 c$ & 2.1 & 2.1 & $\mathrm{ND}$ \\
\hline
\end{tabular}

${ }^{*}$ Summed feature 2 contains $12: 0$ alde and/or an unknown fatty acid; summed feature 3 contains $16: 1 \omega 7 c$ and/or iso-15:0 2-OH.

Table 2. Differentiating characters of the type strains of Aquamicrobium species

Strains: 1, A. defluvii DSM $11603^{\mathrm{T}}$; 2, A. lusatiensis comb. nov. DSM $11099^{\mathrm{T}}$; 3, A. aerolatum sp. nov. Sa $14^{\mathrm{T}}$. None of the substrates analysed by Kämpfer et al. (1991) were utilized. Tests were read after $48 \mathrm{~h}$ of incubation with the exception of hydrolysis of chromogenic substrates, which was read after $24 \mathrm{~h}$. pNP, $p$-Nitrophenyl. All three strains hydrolysed L-alanine $p$-nitroanilide.

\begin{tabular}{|c|c|c|c|}
\hline Test & 1 & 2 & 3 \\
\hline \multicolumn{4}{|l|}{ Acid formation from: } \\
\hline Glucose & + & + & - \\
\hline D-Mannitol & + & - & - \\
\hline myo-Inositol & - & + & - \\
\hline \multicolumn{4}{|l|}{ Hydrolysis of: } \\
\hline pNP phenylphosphonate & - & - & + \\
\hline pNP phosphorylcholine & - & - & + \\
\hline \multicolumn{4}{|l|}{ Assimilation of: } \\
\hline $\mathrm{N}$-Acetyl-D-galactosamine & - & + & - \\
\hline Glucose & + & + & - \\
\hline Adonitol & + & - & - \\
\hline Glutarate & - & + & - \\
\hline DL-3-Hydroxybutyrate & - & + & - \\
\hline DL-Lactate & - & + & - \\
\hline
\end{tabular}


DNA-DNA hybridization experiments were performed between Sa14 ${ }^{\mathrm{T}}$ and A. defluvii DSM $11603^{\mathrm{T}}$ and $D$. lusatiensis DSM $11099^{\mathrm{T}}$ using the method described by Ziemke et al. (1998) except that, for nick translation, $2 \mu \mathrm{g}$ DNA was labelled during a $3 \mathrm{~h}$ incubation at $15{ }^{\circ} \mathrm{C}$. Strain Sa $14^{\mathrm{T}}$ showed relatively low DNA-DNA relatedness to $A$. defluvii DSM $11603^{\mathrm{T}}(22.8 \%)$ and D. lusatiensis DSM $11099^{\mathrm{T}}(22.9 \%)$.

From the results of $16 \mathrm{~S}$ rRNA gene sequence comparison and DNA-DNA hybridization studies and from the chemotaxonomic and physiological characteristics, it is evident that strain Sa14 ${ }^{\mathrm{T}}$ is not a member of either of the species A. defluvii or D. lusatiensis.

All three strains show a remarkable congruence in phenotypic characters. They all produce Q-10 as the major menaquinone. The fatty acid profiles are very similar, being composed mainly of $18: 1 \omega 7 c$ and 19:0 cyclo $\omega 8 c$ (Table 1). Only a few differences in cell morphology and certain physiological tests are apparent (Table 2).

For these reasons, we propose to reclassify Defluvibacter lusatiensis to the genus Aquamicrobium as Aquamicrobium lusatiense comb. nov. A novel species, Aquamicrobium aerolatum sp. nov., is described to accommodate strain Sa $14^{\mathrm{T}}$.

\section{Description of Aquamicrobium lusatiense comb. nov.}

Basonym: Defluvibacter lusatiensis Fritsche et al. 1999.

The description is as given by Fritsche et al. (1999a) with the following amendments. Ubiquinone 10 is the major quinone type. Predominant fatty acids are $18: 1 \omega 7 c$ and 19:0 cyclo $\omega 8 c$. The type strain is strain $\mathrm{S1}^{\mathrm{T}}(=\mathrm{CIP}$ $106844^{\mathrm{T}}=$ DSM $11099^{\mathrm{T}}$ ).

\section{Description of Aquamicrobium aerolatum sp. nov.}

Aquamicrobium aerolatum (ae.ro.la'tum. Gr. n. aer air; L. part. adj. latus -a -um carried; N.L. neut. part. adj. aerolatum airborne).

Cells are Gram-negative, aerobic, rod-shaped and motile, $0.3-0.5 \mu \mathrm{m}$ long and $1.5-2 \mu \mathrm{m}$ wide. Aerobic and oxidasepositive. Good growth after $48 \mathrm{~h}$ on nutrient agar and TSA. Colonies on nutrient agar are smooth, greyish white, translucent and shiny with entire edges. The type strain is unable to grow at 5 or $2{ }^{\circ} \mathrm{C}$. Growth occurs at $\mathrm{pH} 5.5-10$ and $0.9-7 \% \mathrm{NaCl}(\mathrm{w} / \mathrm{v})$. The detailed fatty acid profile is given in Table 1. The type strain is not able to utilize carbohydrates, organic acids or amino acids under the conditions tested. Positive results for tests for alkaline phosphatase and L-alanine aminopeptidase activities.

The type strain is Sa $14^{\mathrm{T}}\left(=\right.$ CCUG $57044^{\mathrm{T}}=$ DSM $\left.21857^{\mathrm{T}}\right)$, isolated from air sampled in a duck shed.

\section{References}

Bambauer, A., Rainey, F. A., Stackebrandt, E. \& Winter, J. (1998a). Characterization of Aquamicrobium defluvii gen. nov., sp. nov., a thiophene-2-carboxylate-metabolizing bacterium from activated sludge. Arch Microbiol 169, 293-302.

Bambauer, A., Rainey, F. A., Stackebrandt, E. \& Winter, J. (1998b). Aquamicrobium defluvii sp. nov. In Validation of Publication of New Names and New Combinations Previously Effectively Published Outside the IJSB, List no. 66. Int J Syst Bacteriol 48, 631-632.

Collins, M. D. (1985). Isoprenoid quinone analyses in bacterial classification and identification. In Chemical Methods in Bacterial Systematics, pp. 267-287. Edited by M. Goodfellow \& D. E. Minnikin. London: Academic Press.

Fritsche, K., Auling, G., Andreesen, J. R. \& Lechner, U. (1999a). Defluvibacter lusatiae gen. nov., sp. nov., a new chlorophenoldegrading member of the $\alpha-2$ subgroup of proteobacteria. Syst Appl Microbiol 22, 197-204.

Fritsche, K., Auling, G., Andreesen, J. R. \& Lechner, U. (1999b). Defluvibacter lusatiensis corrig., sp. nov. In Validation of Publication of New Names and New Combinations Previously Effectively Published Outside the IJSB, List no. 71. Int J Syst Bacteriol 49, 1325-1326.

Gerhardt, P., Murray, R. G. E., Wood, W. A. \& Krieg, N. R. (editors) (1994). Methods for General and Molecular Bacteriology. Washington, DC: American Society for Microbiology.

Grogan, D. W. \& Cronan, J. E. (1997). Cyclopropane ring formation in membrane lipids of bacteria. Microbiol Mol Biol Rev 61, 429-441.

Kämpfer, P. \& Kroppenstedt, R. M. (1996). Numerical analysis of fatty acid patterns of coryneform bacteria and related taxa. Can J Microbiol 42, 989-1005.

Kämpfer, P., Steiof, M. \& Dott, W. (1991). Microbiological characterisation of a fuel-oil contaminated site including numerical identification of heterotrophic water and soil bacteria. Microb Ecol 21, 227-251.

Kämpfer, P., Müller, C., Mau, M., Neef, A., Auling, G., Busse, H.-J., Osborn, A. M. \& Stolz, A. (1999). Description of Pseudaminobacter gen. nov. with two new species, Pseudaminobacter salicylatoxidans sp. nov. and Pseudaminobacter defluvii sp. nov. Int J Syst Bacteriol 49, 887-897.

Kämpfer, P., Dreyer, U., Neef, A., Dott, W. \& Busse, H.-J. (2003). Chryseobacterium defluvii sp. nov., isolated from wastewater. Int J Syst Evol Microbiol 53, 93-97.

Labbé, N., Parent, S. \& Villemur, R. (2004). Nitratireductor aquibiodomus gen. nov., sp. nov., a novel $\alpha$-proteobacterium from the marine denitrification system of the Montreal Biodome (Canada). Int J Syst Evol Microbiol 54, 269-273.

Lechner, U., Baumbach, R., Becker, D., Kitunen, V., Auling, G. \& Salkinoja-Salonen, M. (1995). Degradation of 4-chloro-2-methylphenol by an activated sludge isolate and its taxonomic description. Biodegradation 6, 83-92.

Peix, A., Rivas, R., Trujillo, M. E., Vancanneyt, M., Velázquez, E. \& Willems, A. (2005). Reclassification of Agrobacterium ferrugineum LMG 128 as Hoeflea marina gen. nov., sp. nov. Int J Syst Evol Microbiol 55, 1163-1166.

Tamura, K., Dudley, J., Nei, M. \& Kumar, S. (2007). MEGA4: molecular evolutionary genetics analysis (MEGA) software version 4.0. Mol Biol Evol 24, 1596-1599.

Ziemke, F., Höfle, M. G., Lalucat, J. \& Rosselló-Mora, R. (1998). Reclassification of Shewanella putrefaciens Owen's genomic group II as Shewanella baltica sp. nov. Int J Syst Bacteriol 48, 179-186. 